\title{
Pengaruh Model Inquiri Terbimbing Terhadap Pemahaman Konsep Fisika Siswa Di SMAN Negeri 2 Madapangga
}

\author{
Nurwahidah $^{1}$, Andang ${ }^{2}$, Lis Suswati ${ }^{3}$ \\ ${ }^{1)}$ Pendidikan Fisika, STKIP Bima \\ ${ }^{2)}$ Pendidikan Matematika, STKIP Bima \\ ${ }^{3)}$ Pendidikan Fisika, STKIP Bima \\ Jl. Tendean Kel. Mande Kota Bima-NTB \\ Email : finayuliI23@gmail.com
}

\begin{abstract}
ABSTRAK : Penelitian ini bertujuan untuk mengetahui pengaruh model inquiri terbimbing terhadap pemahaman konsep fisika siswa SMA Negeri 2 Madapangga kelas XI semester I. Jenis Penelitian ini adalah quasi eksperimen. Pengambilan sampel dilakukan dengan cara Sampling Jenuh dengan mengambil 2 kelas. Sampelnya kelas XI IPAI sebagai kelas eksperimen dengan jumlah siswa 32 orang dan XI IPA2 sebagai kelas kontrol dengan jumlah siswa 32 orang. Instrumen yang digunakan pada penelitian ini berupa tes (pretest dan posttest) dan uji N-Gain. Hasil analisis dari uji N-Gain diperoleh untuk kelas kontrol adalah 0,44 sedangkan untuk kelas eksperimen adalah 0,60. Hasil uji t yang diperoleh menunjukkan bahwa thitung $=0,27$ dibandingkan dengan tabel $=$ I,9989 untuk taraf signifikansi 5\% atau $\alpha=0,05$. Hasil pengujian hipotesis pada penelitan ini thitung $<$ tabel, maka dapat disimpulkan dalam penelitian ini tidak terdapat pengaruh model inquiri terbimbing terhadap pemahaman konsep fisika siswa SMA Negeri 2 Madapangga tahun pelajaran 2018/2019.
\end{abstract}

\section{Kata kunci: Inquiri Terbimbing dan Pemahaman Konsep}

\section{PENDAHULUAN}

Pendidikan yang berkualitas mampu menghasilkan sumber daya manusia yang berkualitas. Pendidikan pada dasarnya adalah usaha sadar yang dapat mengembangkan potensi diri seseorang, sehingga terbentuklah kepribadian dan keterampilan yang baik yang dapat berguna bagi dirinya sendiri, masyarakat dan negara. Upaya dalam meningkatkan mutu pendidikan adalah usaha yang dilakukan oleh pemerintah, antara lain peningkatan kualitas pendidikan guru, mengadakan sarana dan prasarana serta melaksanakan perubahan kurikulum. Guru sebagai tenaga pendidik memegang peranan utama dan sebagai ujung tombak dalam proses belajar mengajar [I].

Seiring dengan perkembangan ilmu pengetahuan dan teknologi fisika sebagai salah satu ilmu dasar yang semakin dirasakan kegunaannya untuk kalangan umum, namun pada kenyataan mata pelajaran fisika disetiap jenjang pendidikan perlu mendapatkan perhatian yang lebih oleh kalangan pendidikan, karena sampai saat ini mata pelajaran fisika masih kurang diminati karena dianggap sulit. Penyataan tersebut sesuai dengan hasil observasi di SMA Negeri 2 Madapangga tahun pelajaran 2018/2019. Anggapan bahwa fisika sulit dan kurang diminati tidak muncul dari pernyataan peserta didik saja. Ada 3 sumber utama peserta didik kesulitan mempelajari fisika yang dijelaskan yaitu: faktor guru, alam, kurikulim [2].

Berdasarkan observasi awal di sekolah SMA Negeri 2 Madapangga Kabupaten Bima, didapatkan data yang diperoleh peneliti dari guru mata pelajaran fisika, bahwa hasil belajar fisika kelas XI SMA Negeri 2 Madapangga Kabupaten Bima tahun pelajaran 2017/2018 tergolong rendah. Hal ini terlihat dari nilai rata-rata skor belajar siswa satu tahun terakhir mencapai 60,00. Hasil nilai rata-rata tersebut belum mencapai standar kompetensi yang telah ditentukan dalam kriteria ketuntasan minimal mata pelajaran fisika. Sedangkan nilai KKM yang ditentukan oleh sekolah tersebut adalah 75,00.
Data tersebut menunjukkan rendahnya hasil belajar fisika, hal ini terlihat jelas mata pelajaran fisika hingga saat ini masih kurang diminati.

Berdasarkan data tersebut kurangnya minat siswa terhadap mata pelajaran fisika disebabkan oleh beberapa faktor: I) Metode yang digunakan saat proses belajar mengajar adalah masih menggunakan metode konvensional atau metode ceramah sehingga pengajaran berpusat pada guru dan hasilnya siswa cenderung pasif. 2) Pemahaman akan konsep dan perhitungan masih kurang, padahal mata pelajaran fisika yang syarat dengan konsep dan perhitungan. 3) Banyaknya konsep fisika yang bersifat abstrak yang harus diserap siswa dalam waktu yang relatif terbatas menjadikan ilmu fisika merupakan salah satu mata pelajaran tersulit bagi siswa saat ini. Siswa cenderung belajar dengan hafalan dari pada secara aktif membangun pemahaman mereka sendiri terhadap konsep fisika tersebut. Akibatnya banyak siswa yang gagal dalam belajar fisika.

Khususnya mata pelajaran fisika dalam proses belajar mengajar, metode dan pendekatan yang digunakan dalam satu konsep belum tentu cocok dengan konsep lain karena metode atau pendekatan yang digunakan dalam proses belajar mengajar masing-masing memiliki kelebihan dan kekurangan. Hal ini dapat terungkap melalui peningkatan pemahaman siswa terhadap suatu konsep sesuai bahan ajar yang diajarkan [3]. Salah satu model pembelajaran yang relevan dan sesuai dengan permintaan kurikulum adalah Model Inquiri Terbimbing. Inquiri adalah suatu rangkaian kegiatan pembelajaran yang melibatkan secara maksimal seluruh kemampuan peserta didik untuk mencari dan menyelidiki secara sistematis, kritis dan logis sehingga mereka dapat menemukan sendiri pengetahuan, sikap dan keterampilan sebagai wujud adanya perubahan prilaku [4].

Inquiri terbimbing merupakan bagian inti dari kegiatan pembelajaran berbasis discovery. Pengetahuan dan keterampilan yang diperoleh siswa diharapkan bukan hasil mengingat seperangkat fakta-fakta, tetapi hasil dari menemukan sendiri. 
Sehingga pembelajaran inquiri terbimbing merupakan kegiatan pembelajaran yang melibatkan secara maksimal seluruh kemampuan siswa untuk mencari dan menyelidiki sesuatu (benda, manusia atau pristiwa) secara sistematis, kritis, logis, analitis sehingga mereka dapat merumuskan sendiri penemuannya dengan penuh percaya diri Berdasarkan uraian tersebut, peneliti tertarik untuk melakukan penelitian dengan judul "Pengaruh Model Pembelajaran Inquiri Terbimbing Terhadap Pemahaman Konsep Fisika Siswa SMA Negeri 2 Madapangga Tahun Pelajaran 2018/2019”.

\section{METODE PENELITIAN}

Penelitian ini dilaksanakan di SMAN 2 Madapangga. Penelitian ini merupakan jenis kuasi eksperimen (quasi experiment) sehingga peneliti dapat mengontrol secara penuh ciri-ciri dan karakteristik sampel yang akan diteliti serta menggunakan rancangan yang memungkinkan pengontrolan pada situasi yang ada. Eksperimen semu merupakan jenis eksperimen yang belum memenuhi persyaratan seperti cara eksperimen yang dapat dikatakan ilmiah mengikuti peraturanperaturan tertentu [5].

Desain penelitian yang digunakan pada penelitian ini adalah Posttest and pretest Control Group Design [6]. Rancangan ini melibatkan keterampilan proses sains dari dua kelompok yang dibandingkan yaitu. Populasi dalam penelian ini adalah seluruh siswa kelas XI SMA Negeri 2 Madapangga. Pengambilan sampel pada penelitian ini menggunakan teknik Sampling jenuh dikarenakan semua jumlah populasi digunakan sebagai sampel. Adapun sampel pada penelitian ini yaitu kelas XI IPAI sebagai kelas eksperimen dan XI IPA2 sebagai kelas kontrol. Prosedur yang dilaksanakan dalam penelitan ini terdiri dari tiga tahap yaitu tahap persiapan penelitian, tahap pelaksanaan penelitian dan tahap akhir penelitian.

Instrumen penelitian yang digunakan dalam penelitian ini antara lain instrumen untuk mengukur pemahaman konsep, yaitu tes pemahaman konsep (nilai posttest) pada pembelajaran fisika setelah diberikan perlakuan (treatment) dan uji N-Gain. Sebelum soal dianalisis, terlebih dahulu dilakukan uji coba instrumen berupa uji validitas dan reliabilitas soal. Teknik pengumpulan data dengan non tes dilakukan menggunakan angket (kuosioner). Tujuan dari pengumpulan data secara non tes ini untuk mengetahui kelayakan model pembelajaran inquiri berdasarkan respon siswa terhadap pemahaman konsep. Teknik pengumpulan data pada penelitian ini dengan Tes, observasi, dan dokumentasi. Untuk melihat besarnya peningkatan pemahaman konsep siswa digunakan uji $\mathrm{N}$-Gain ternormalisasi selain itu dilakukan uji $\mathrm{t}$ untuk menguji hipotesis penelitian. Sebelum melakukan uji t terlebih dahulu dilakukan uji prasyarat analisis terdiri atas uji normalitas dan uji homogenitas.

\section{HASIL DAN PEMBAHASAN}

Penelitian ini dilaksanakan dengan tujuan untuk mengetahui pengaruh model pembelajaran inquiri terbimbing terhadap pemahaman konsep fisika siswa SMA Negeri 2 Madapangga dengan sub pokok materi Elastisitas dan Hukum Hoke. Sebelum menganalisis data, peneliti terlebih dahulu melakukan uji instrumen yang terdiri dari dua uji yaitu uji validitas dan uji reliabilitas, dimana uji valiiditas itu sendiri untuk mengetahui layak atau tidaknya soal yang akan digunakan pada penelitian

Terdapat 8 soal yang diuji cobakan diperoleh 6 soal yang valid dan 2 soal yang tidak valid dikarenakan bahasa soal yang kurang dimengerti oleh siswa. Soal dinyatakan valid atau dapat digunakan apabila rhitung lebih besar dari rtabel. Uji coba reliabilitas dilakukan pada 6 soal yang sudah valid dengan menggunakan rumus alpha dan nilai rtabel untuk taraf signifikasi $5 \%$ dengan $\mathrm{n}=6$, maka diperoleh nilai sebesar 0,3269 menggunakan rumus alpha.

Setelah diberikan perlakuan (kegiatan proses belajar mengajar selesai). Siswa diberikan posttest guna untuk mengukur sejauh mana mereka dapat memahami pelajaran yang telah diajarkan. Adapun hasil postestt kelas kontrol diperoleh nilai terendah 65 dan nilai tertinggi 95, maka didapatkan nilai rata-rata kelas kontrol sebesar 79,84. Sedangkan kelas eksperimen nilai rendah 70 dan nilai tertinggi I00, maka nilai rata-rata didapatkan 86,09.

Berdasarkan hasil analisis deskripsi, menunjukkan bahwa pemahaman konsep siswa pada sub pokok materi elastisitas dan hukum hoke mengalami peningkatan yang cukup signifikan dengan diterapkannya model pembelajaran inquiri terbimbing tersebut. Hal ini dapat dilihat dari perbedaan nilai rata-rata baik untuk rata-rata pretest maupun rata-rata posttest pada kelas eksperimen maupun kelas kontrol. Untuk rata-rata pretest pada kelas eksperimen bernilai 70,68 sedangkan pada kelas kontrol bernilai 62,34. Dan untuk rata-rata posttest, bernilai 83,43 untuk kelas eksperimen dan 78,90 untuk kelas kontrol. Dan untuk analisis deskriptif pemahaman konsep dengan menggunakan rumus $\mathrm{N}$-Gain, mendapatkan nilai 0,435 dengan kriteria yang tergolong sedang.

Sedangkan hasil analisis uji normalitas dengan menggunakan uji Chi-kuadrat menunjukkan bahwa data pemahaman konsep dengan menggunakan model pembelajaran Inquiri terbimbing diperoleh nilai $X^{2}$ hitung $=9,35305 \mathrm{I}<$ $\mathrm{X}^{2}$ tabel $=$ II,070498; maka berdasarkan kriteria pengujian berarti pemahaman konsep fisika siswa yang diajarkan dengan menggunakan model pembelajaran Inquiri terbimbing berdistribusi normal. Jika $\mathrm{X}^{2}$ hitung $<\mathrm{X}^{2}$ tabel pada taraf signifikan $\alpha=0,05 \mathrm{dan} d \mathrm{k}=\mathrm{k}-\mathrm{I}$. Dengan demikian data yang dianalisis berdistribusi normal. Dalam pengujian homogenitas, uji yang digunakan adalah dengan menggunakan uji F. Dari analisis yang dilakukan diperoleh hasil dengan nilai $\mathrm{F}$ hitung $=0,68526$ dan $F$ tabel $=1,80482$. Dengan demikian, maka dapat ditarik kesimpulan bahwa data penelitian bersifat homogen karena $\mathrm{F}$ hitung $<\mathrm{F}$ tabel.

Analisis deskripsi pengujian hipotesis yang dilakukan guna melihat pengaruh pembelajaran inquiri terhadap pemahaman konsep fisika siswa dengan menggunakan uji-t diperolah hasil bahwa t hitung $=0,27$ dengan taraf signifikan $(\boldsymbol{\alpha})=0,05$ dan derajat kebebasan $(\mathrm{dk})=\mathrm{nI}+\mathrm{n} 2-2=62$ sehingga didapat $\mathrm{t}$ tabel $=$ I,9989. Dengan demikian dapat disimpulkan bahwa tidak terdapat pengaruh model pembelajaran inquiri terbimbing terhadap pemahaman konsep fisika siswa kelas XI IPAI SMA Negeri 2 Madapangga tahun pelajaran 2018/2019 dikarenakan: I) Rendahnya kemampuan guru dalam penyampaian materi pembelajaran. 2) Tingkat kemampuan individual siswa rendah. 3) Tingkat reliabilitas soal tergolong rendah. 
Hasil yang diperoleh dalam penelitian ini adalah a) siswa mampu mengembangkan potensi yang dalam diri mereka yang ditunjukkan dengan menjawab soal yang telah diajukkan. b) siswa dapat memahami konsep-konsep pembelajaran dalam fisika. Setiap proses pembelajaran tidak selamanya berlangsung baik dan sesuai yang diharapkan. Berdasarkan identifikasi ketika proses pembelajaran bahwa lemahnya kemampuan siswa dalam belajar fisika bukan hanya disebabkan karena siswa tidak bisa memahami konsep yang berikan tetapi juga karena model serta metode pembelajaran yang digunakan. Model inquiry memberi warna baru pada proses pembelajaran walaupun mereka harus belajar beradaptasi dengan model inqury. Model inquiry mendorong siswa lebih memahami konsep elastisitas hal ini dapat dilihat dari peningkatan nilai uji N-Gain, walaupun dengan uji t menunjukan tidak ada pengaruh.

\section{KESIMPULAN}

Berdasarkan hasil analisis dan pengujian hipotesis dapat ditarik kesimpulan bahwa tidak terdapat pengaruh model Inquiri Terbimbing Terhadap Pemahaman Konsep Fisika Siswa SMA Negeri 2 Madapangga tahun pelajaran 2018/2019. Hal ini terbukti dari hasil perhitungan bahwa $\mathrm{t}$ hitung $=0,27>\mathrm{t}$ tabel $=1,9989$.

\section{DAFTAR PUSTAKA}

[I] Depdiknas, RI. 2003. UU No. 20 Tahun 2003 Tentang Sistem Pendidikan Nasional. Jakarta: Depdiknas.

[2] Erinosho, S.Y. 2013. How do students perceive the difficulty of physics in secondary school? An exploratory study in Nigeria. International journa for Cross-Disciplinaty Subjects in Education (IJCDSA), 3,3. Diambil pada tanggal 2 Mei 2017, dari http://infonomics-society.org. wpcontent/uploads/ijcdse/published-papers/specialissue-volume-3-2013/How-Do-Students-Perceivethe-difficuly-of-Physics-in-Secondary-School.pdf.

[3] Trianto, S. 2007. Model-Model Pembelajaran Inovatif Berorientasi Konstruktivistik.. Jakarta: Prestasi Pustaka

[4] Hanafiah, Nanang, dkk. 20I0. Konsep Strategi Pembelajaran. Bandung: PT Refika Aditama.

[5] Arikunto, Suharsimi. 2010. Prosedur Penelitian Suatu Pendekatan Praktik. Jakarta: PT Rineka Cipta.

[6] Fraenkel, J. R. and Wallen, N.E. 2009. How to Design and Evaluate Researchin Education (7th ed.). Boston: Mc Graw-Hill. 